\title{
Supersivion Program in Improving Teachers Profesional Competence at SD Negeri 5 Juli, Bireun Regency
}

\author{
Yusnidar ${ }^{1}$, Murniati ${ }^{2}$, Khairuddin ${ }^{2}$ \\ ${ }^{1}$ Master of Education Administration, Universitas Syiah Kuala, Indonesia. \\ ${ }^{2}$ Universitas Syiah Kuala, Indonesia. \\ *Corresponding email: yusnidar@gmail.com
}

Received: 18 April 2021

Accepted: 28 July 2021

Published: 29 August 2021

Abstract: The aim of the study was to determine the supervisory program, implementation of supervision to improve the professional ability of teachers in the SD Negeri 5 Juli in Bireun district. This study uses a descriptive method with a qualitative approach. Data collection was carried out by observations, interviews, and documentation. The subject of this study is the supervisor, principal, head of the teacher's work team, and senior teacher. Data collection techniques through: observation, interviews and documentation studies. Data analysis was carried out by using data reduction, data presentation and withdrawal of conclusions. The results of the study show: (1) The supervisory program consists of annual plans and semesters. (2) Surveillance has been running with efforts to improve teacher competence professionally. Such supervision programs include classroom supervision, class observations, Improwage quizzes, case documentation, interviews, questionnaires, and written reports; (3) The obstacles faced in supervision are the absence of coordination between the supervisor and the principal and teacher on the schedule of the meeting.

Keywords: supervision implementation, supervisors, profesional teachers.

Abstrak: Tujuan penelitian untuk mengetahui program supervisi, pelaksanaan supervisi untuk meningkatkan kemampuan profesional guru di SD Negeri 5 Juli Kabupaten Bireun. Penelitian ini menggunakan metode deskriptif dengan pendekatan kualitatif. Pengumpulan data dilakukan dengan observasi, wawancara, dan dokumentasi. Subjek penelitian ini adalah supervisor, kepala sekolah, ketua tim kerja guru, dan guru senior. Teknik pengumpulan data melalui: observasi, wawancara dan studi dokumentasi. Analisis data dilakukan dengan menggunakan reduksi data, penyajian data dan penarikan kesimpulan. Hasil penelitian menunjukkan: (1) Program supervisi terdiri dari rencana tahunan dan semester. (2) Pengawasan telah berjalan dengan upaya peningkatan kompetensi guru secara profesional. Program supervisi tersebut meliputi supervisi kelas, observasi kelas, kuis Imrowage, dokumentasi kasus, wawancara, angket, dan laporan tertulis; (3) Kendala yang dihadapi dalam supervisi adalah tidak adanya koordinasi antara supervisor dengan kepala sekolah dan guru pada jadwal pertemuan.

Kata kunci: penerapan supervisi, supervisor, guru profesional.

\section{To cite this article:}

Yusnidar, Murniati, \& Khairuddin. (2021). Supersivion Program in Improving Teachers Profesional Competence at SD Negeri 5, Bireun Regency. Jurnal Pendidikan Progresif, 11(2), 464-471. doi: 10.23960/jpp.v11.i2.202127. 


\section{INTRODUCTION}

School as one of the formal educational institutions that has been known and has received public recognition since the past with its main task to educate the life of the nation. As an institution, school education functions as a means to develop quality Indonesian human resources. The purpose of education in schools is in line with the goals of national education which are essentially to educate the life of the nation or students in school (DePaoli et.al., 2018; Epstein et.al., 2018; Maryam et.al., 2018).

Increasing human resources that have global quality is a concrete offer to maintain the existence of life, increase the dignity of a nation. Education is a key variable in the effort to produce quality human resources (Curran \& Standage, 2017; Strimel \& Grubbs, 2016). Non-quality education can certainly not be able to produce quality human resources, therefore in the context of preparing and producing quality human resources, quality education is needed. Thus, it provides clarity that reliable human resources will only be obtained, if the education process can be implemented properly. In addition, to realize good education, it is necessary to develop optimal learning situations in schools. One effort to achieve this process is through effective academic supervision in school (Renata, Wardiah, \& Kristiawan, 2018; Sappaile et.al., 2018; Makau, Ronoh, \& Tanui, 2016).

In general, the purpose of supervision is to develop better learning and teaching situations. Efforts towards improving the learning and teaching situation are aimed at achieving the goal of education, namely the formation of a maximum of children's personal The learning situation in schools now illustrates very complex problems. All problems that arise in formal education institutions, in reality have an impact on the decline in student learning achievement in schools, even in general have an impact on the decline in the quality of education. The existence of objective factors that influence each other so that it results in decreased learning outcomes. Therefore, it is necessary to create a situation that allows students to learn well and teachers can guide in a creative atmosphere where they feel more stable in their profession as teachers.

The process of education and teaching that takes place in an educational institution requires systematic and planned coordinating efforts. One of the efforts in this direction can be realized through the implementation of supervision. Supervision is nothing but the application of the principles of democracy, so that human potential can develop continuously, both in a personal and shared context, so that everyone can participate in a community.

In terms of education, supervision is defined by the guidance given to all school staff so that they can improve their ability to develop better teaching and learning situations. This understanding shows that not only teachers are became the target of supervision, but also included other personnel at the school. Supervision can also be done by school supervisors in the work area of the District Education Office.

The problem is, there are still supervisors who do not carry out routine supervision tasks, so that they have a negative impact on teacher professionalism in carrying out learning activities, such as lack of motivation and decreased performance. In addition, it can have an impact on the deterioration of the quality of educational institutions, which is indicated by the lack of interest of parents to send their children to certain elementary schools in the UPT Juli Region of Bireuen Regency. The 2015-2016 school year numbered 180 students, the 2016-2017 school year for incoming students was only 92 people, thus a decline of around $50 \%$.

THEORETICAL FOUNDATION 
Supervision is all the help of the school leaders, which is focused on the development of the leadership of teachers and other personal schools in achieving educational objectives (Carroll et.al., 2020; Mette, Fairman, \& Terzi, 2017; Johnston, Kaufman, \& Thompson, 2016). Supervision is a management strategy consisting of a series of activities to ensure that the quality expected in the planning, implementation of activities, and evaluation meets predefined standards (Darishah, Daud, \& Omar, 2017; Ruan, \& Liu, 2017).

The main function of teaching supervision is the effort to improve and improve the teaching quality and to build a teaching program so that there is always improvement effort. Curriculum and supervision are two areas of interconnectedness between each other (Chizhik, Chizhik, Close, \& Gallego, 2017; Mette et.al., 2017; Burns, Jacobs, \& Yendol-Hoppey, 2016; Supervision and curriculum are two areas of duty that are closely related because supervision is implemented in the framework of the implementation of the curriculum. As such, the supervision functions among them coordinate all school ventures, equip school Leadership, expand teachers ' experience, stimulate creative efforts, provide continuous facilities and assessments, Analyzing the learning situation, equiping each staffmember with new knowledge and skills, and giving a broader and more integrated insight into formulating teaching objectives and improving teacher teaching skills.

Supervision to motivate teachers, means supervisor builds, promotes motivation and enhances teacher's commitment to teaching, encourages teachers to apply their skills in carrying out his or her teaching duties, encourages teachers to develop his or her ability and encouraging teachers to have earnest attention to their duties and responsibilities, through supervision, supervisors can cultivate the motivation of teacher work.
In relation to the management and leadership of the headmaster, supervision is more emphasized on the coaching and improvement of the ability and performance of educational personnel in the school to perform the task. The goal of supervision is to create good performance among the teachers, so that they become professional personnel. Professionals are rooted in the tendency to develop specializations in the world of work and community life. In the life of modern society, it takes competent and professional personnel. To prepare a person as a professional teacher, pre-service and inservice instruction is required.

The success of school education is not separated from the role of supervisors, principals, and teachers (Aceron, \& Guerrero, 2018; Grissom, Blissett, \& Mitani, 2018; Bachri Thalib, 2016; Range, Hewitt, \& Young, 2016). The principal task of the teacher is to teach and help students solve their personal and social learning and development problems. Principals lead teachers and students in the learning process and help address the problems faced by supervisors in supervision and providing assistance to principals, teachers, and students in addressing the issues faced during the Education takes place.

Supervision is a direct oversight aimed at improving the learning situation in the classroom, it means that supervision is more geared towards teachers and students in the teaching and learning process. The issue of quality learning concerns a very essential problem that the teaching quality problems performed by teachers must continue to be sustained and continuous supervision and coaching, the problem is closely related to the supervision of the principal to his teachers.

If the principal as a supervisor wants to face the entire staff, there can be meetings that are direct communication also. If the group can not be gathered at once, can also be used circular 
letters, newsletters, announcements and so on. If the supervision is greater and covers the wider parties, seminars can be held, or can also be with a workshop. The techniques of supervision that are prevalent and regularly can be performed by the headmaster are: school meetings, class visits, deliberations or individual gatherings. These activities are already prevalent, done by every school principal in their respective schools, but in the way the implementation may still be less aware of the purpose of the principles of supervision. "The principle of supervision in general is the principle of improvement, communicative, prevention, control, objective, and continuity. While the modern principle is to create a good relationship of teachers and Gtenaga education, is democratic, and comprehensive.

Primary school teachers should not only serve as teachers, but also as advisers and educators for their students at school. The role of teachers in the teaching and learning process in schools, according to Sardiman, Informator, Organisator, Motivator, Director, Initiator, Transmitter, Fasilisator, Mediator, Evaluator. The provision of competent teacher resources (who have professional skills) is very large in the success or failure of the teaching process in elementary school. Without a competent teacher, the quality of education will not increase. More clearly concerning the competency of teachers in the teaching process, according to Sardiman 1, mastery of materials; (2) Manage teaching and learning programs; (3) Managing classes; (4) Use the source media; (5) Mastering educational foundations; (6) Manage teaching learning interactions; (7)Assessing student achievement; (8) To identify functions and mentoring programs in schools; (9) To recognize and administer school administration; (10) Understand the principles and interpret the research results for teaching purposes.

\section{METHODS}

The approach used in this research was a qualitative approach in a descriptive method, which is to explain and illustrate Supersivion Done By Supervisor In Improving Teachers Profesional Competence At State Elementary School 5 Of Juli In Bireun Regency. "a qualitative research could be perceived as a research method that based on the postpositivism philosophy, which used to examine a natural object, where the researcher act as the key instrument, analysis technique and inductive, and the result of research emphasize on the meaning instead of a generalization. The subject of this research is the principal of Darul Abrar of Aceh Jaya, as the main subject providing data for this research, and the supervisor and teachers working at School 5 July Education Office of Bireuen District. Data collection technique conducted through observation, interview and documentation study. Observation is conducted to check data correctness about the managerial role of the principal, an interview is conducted to discover more in-depth things regarding the situation and phenomenons, and document study is conducted to interpret all documents according to the focused problem. Data analysis is conducted by the steps of data reduction, data visualization, and data verification.

\section{RESULTS AND DISCUSSION}

Supervision Program by a supervising the professional competence of teachers on the state elementary School 5 July Education Office of Bireuen District.

The initial step to realize a success or achieve a goal begins with the preparation of the program. Programming is part of the management 
process that has a very important meaning. Likewise, the coordination of supervisors with school principals in Bireuen District in improving teacher performance at the 5th July Public Elementary School in Bireuen District. Ideally the supervisor prepares a short-term, mid-term and long-term supervision program for the next five years whose emphasis is directed at improving the quality of the learning process. The expected real form of supervision includes: fulfilling the need for complete facilities for supervision and ideas in developing the quality of target schools for the overall implementation of the July 5 Public Education in Bireuen District.

The preparation of an academic supervision program emphasizes the development of the teacher's ability to carry out the learning process. That is, the field of supervision assignments is within the scope of conducting learning improvement efforts. However, the firmness of the scope does not yet appear in its implementation, because in its implementation the components which become the supervision task area cover the administrative and educational aspects. In connection with this"to strengthen the existence and grow the role of supervision as it should be, efforts are needed to reinforce the field of duty and performance of educational supervision. Supervision performance is more related to teaching and improvement activities.

Based on the quotation above, it gives clarity that the task area of the supervisor must be focused on teaching and improvement activities so that the existence and role of supervision can be seen. In addition, the supervision instruments used must be corrected and developed. The instrument used should contain instructions, based on these instructions the supervisor develops the supervision instrument according to the conditions encountered during the initial meeting stage.
Supervisors prepare reports on the results of supervision, analyze, process data, and solve problems. More carefully for the benefit of the learning process carried out by the teacher in the class. One of the supervisors' performance that should not be ignored and is the obligation of every supervisor, is to provide a complete written report to the Head of the Bireuen District Education Office and provide a complete copy to the Province. Provision of reports is the control carried out by the superior unit to the supervisors who have carried out the tasks periodically.

Implementation of supervision by the supervisor to improve the competency of professional teachers in elementary school July 5, Bireuen District.

The results of the study showed that the implementation of the supervision program at the 5th July Public Elementary School in Bireuen District was in a good category. In general, the aspects of teacher development and development carried out by supervisors have been carried out and have led to efforts to improve teacher professionalism. This is evidenced by the changes made by the teachers in the learning process in front of the class. In addition, the enthusiasm of the elementary school teacher to improve his weaknesses is quite high. Especially in preparing learning tools as expected.

The process of implementing the supervision program can be carried out consequently, so it is certain that it can improve the learning process carried out by the teacher, that is, from being less effective becomes more effective and from less meaningful will become more meaningful.

A job must be carried out systematically, synergistically, and continuously to produce optimal results. This, all can be realized properly, if the supervisors of teaching can work well and effectively. Work effectiveness is largely determined by the extent to which the motivation it has in carrying out its tasks. Regarding the 
motivation of the work of the teacher, The motivation of teacher work can be low, can be high. A teacher who has high work motivation will have a strong will or sincerity to carry out his duties, and consequently his productivity will increase. Conversely, a teacher who has low work motivation will have less willingness to do his tasks, and consequently productivity will decrease.

Professional teacher development is an important matter and needs serious attention from supervisors so that good quality teachers are expected to improve the quality of student learning in schools. Professional teachers, ideally capable of carrying out their tasks well.

Implementation constraints of supervision by the Supervisor to improve the competence of professional teachers on the state elementary school July 5 Bireuen district.

The results of the study show that the process of implementing the 5 July supervision of the District of Bireuen is still faced with several problems, including the distance and the extent of the area is one of the main obstacles. It was realized that for remote areas in Bireuen it requires special preparation and time for supervisors to come to the area. This condition causes the routine attendance of supervisors to schools to carry out academic supervision activities.

Another obstacle is that to make a visit to a particular school, sometimes the target is not achieved as programmed, either because there is no time for the principal and the attendance of the teacher in question, making it difficult to choose and reschedule the failed visit. When there are obstacles, ideally problem solving efforts should be carried out, especially by increasing coordination between supervisors and school principals.

Another obstacle in the process of academic supervision is that all this time academic supervision activities carried out by supervisors from the Department of Education as well as by principals as internal supervisors are not continuous. Professional teacher development should be carried out continuously through various activities, so that teachers can develop optimally. Professional competence is the mastery of learning material widely and deeply, which includes mastery of curriculum material in school subjects and scientific substance that overshadow the material, as well as mastery of scientific structures and methodologies.

The ability of teachers and facilitating students in the learning process greatly influences the quality of education. Moreover, the preparation of good learning tools is very important directed by supervisors or principals as supervisors. Actually the lesson plan is very important to be understood by the teacher, because in it there are activities that must be done by the teacher in presenting the material to the students. Learning Implementation Plan (RPP) is a description of the syllabus that has been compiled in the previous step. In the lesson plan the activities carried out by the teacher and the students are reflected in achieving the stated competencies. In another sense, the implementation of the learning plan is a plan that describes the procedures and organization of learning to achieve a basic competency set out in the Content Standard and described in the syllabus.

The results of the study indicate that supervision activities do exist and are carried out by supervisors and classified as inadequate. Likewise only with coordination, there are still supervisors who do not coordinate intensely with the principal before coming to school to conduct supervision activities.

CONCLUSIONS 
The supervision implementation program is compiled, covering annual and semester work programs. Supervisors carry out supervision activities, conduct guidance, guide, and direct teachers to improve their teaching abilities.

Implementation of supervision by supervisors has been carried out and has led to efforts to improve teacher professional competence. Supervision activities carried out include classroom guidance, class observation, impromptu tests, case conferences, documentation, interviews, questionnaires, and written reports.

Constraints encountered in the implementation of supervision include the lack of good coordination between supervisors and principals and teachers, concerning adjusting meeting schedules. Another obstacle is that supervision activities carried out by supervisors are not continuous at the 5th July Public Elementary School in Bireuen District.

\section{REFERENCES}

Aceron, L. O., \& Guerrero, J. G. (2018). Principals' Relationships towards Teachers: Its Impact to Schools' Management and Success. International Journal of Recent Innovations in Academic Research, 2(6), 178-185.

Bachri Thalib, S. (2016). the effect of school supervisors competence and school principals compotence on work motivation and performance of junior high school teachers in maros regency, indonesia. International Journal of Environmental and Science Education, 11(15), 7310-7317.

Burns, R. W., Jacobs, J., \& Yendol-Hoppey, D. (2016). The changing nature of the role of the university supervisor and function of preservice teacher supervision in an era of clinically-rich practice. Action in Teacher Education, 38(4), 410-425.

Carroll, C., Brackenbury, G., Lee, F., Esposito, R., \& O’Brien, T. (2020). Professional Supervision: Guidance for SENCOs and school leaders.

Chizhik, E. W., Chizhik, A. W., Close, C., \& Gallego, M. (2017). SMILE (Shared Mentoring in Instructional Learning Environments) Effectiveness of a Lesson-Study Approach to StudentTeaching Supervision on a TeacherEducation Performance Assessment. Teacher Education Quarterly, 44(2), 27-47.

Curran, T., \& Standage, M. (2017). Psychological needs and the quality of student engagement in physical education: Teachers as key facilitators. Journal of teaching in physical education, 36(3), 262-276.

Darishah, P., Daud, Y., \& Omar, F. M. S. (2017). Teaching and learning supervision by school management, attitude of teachers and competency of teaching. International Journal of Development and Sustainability, 6(10), 1367-1381.

DePaoli, J. L., Balfanz, R., Atwell, M. N., \& Bridgeland, J. (2018). Building a Grad Nation: Progress and Challenge in Raising High School Graduation Rates. Annual Update 2018. Civic Enterprises.

Epstein, J. L., Sanders, M. G., Sheldon, S. B., Simon, B. S., Salinas, K. C., Jansorn, N. R., ... \& Hutchins, D. J. (2018). School, family, and community partnerships: Your handbook for action. Corwin Press.

Grissom, J. A., Blissett, R. S., \& Mitani, H. (2018). Evaluating school principals: Supervisor ratings of principal practice and principal job performance. 
Educational Evaluation and Policy Analysis, 40(3), 446-472.

Johnston, W. R., Kaufman, J. H., \& Thompson, L. E. (2016). Support for instructional leadership: Supervision, mentoring, and professional development for US school leaders: Findings from the American School Leader Panel.

Makau, N. N., Ronoh, A., \& Tanui, E. (2016). Relationship between principals' instructional supervision and students' academic achievement in sciences in secondary schools.

Maryam, S., Amen, U. E., Safdar, A., Shehzadi, A., \& Abbas, S. (2018). Education to Educate: A Case of Punjab Education Foundation. International Journal of Advanced Engineering, Management and Science, 4(6), 460-465.

Mette, I. M., Fairman, J. C., \& Terzi, S. D. (2017). Strategies, supports, and supervision of teacher leaders and development of future school leaders. University of Maine, College of Education and Human Development, Maine Education Policy Research Institute.

Mette, I. M., Range, B. G., Anderson, J., Hvidston, D. J., Nieuwenhuizen, L., \& Doty, J. (2017). The wicked problem of the intersection between supervision and evaluation. International Electronic Journal of Elementary Education, 9(3), 709-724.

Range, B., Hewitt, P., \& Young, S. (2016). Principals' perceived supervisory behaviors regarding marginal teachers in two states. Administrative Issues Journal: Connecting Education, Practice, and Research, 4(1), 544.

Renata, R., Wardiah, D., \& Kristiawan, M. (2018). The Influence of Headmaster's Supervision And Achievement Motivation On Effective Teachers.
International Journal of Scientific \& Technology Research, 7(4).

Ruan, X. P., \& Liu, S. J. (2017). Research on the Function of Accounting Supervision in the Network Enterprise Management Ruan. DEStech Transactions on Engineering and Technology Research, (mcee).

Sappaile, B. I., Masuddin, L. O., Saludung, J., Sappaile, P., Ishak, A. M., Simatupang, W., \& Abdullah, S. (2018). Influence of implementation of academic supervision by the school supervisor, interpersonal communication, and teacher motivation on the quality of learning in secondary high schools in regency of South Buton, Indonesia. Journal of Educational Research and Reviews, 6(2), 29-37.

Strimel, G., \& Grubbs, M. E. (2016). Positioning technology and engineering education as a key force in STEM education. Journal of Technology Education, 27(2), 21-36. 